\title{
Border water culture in theory and practice: political behavior on the Mexico-U.S. border
}

\author{
Carmen Maganda ${ }^{1}$ \\ University of Luxembourg, Luxembourg
}

\section{Introduction}

Border regions have a life of their own. Borders, once seen as divisions between conjoining states, have been reinterpreted by many scholars as transnational regions that are dynamic areas of opportunity and exchange. It is this lively environment that has given rise to the notion of cross-border cultures, which can be transnational ethnic communities (i.e. the Basques in Spain and France) or cross-border social movements (i.e. those fighting for migrants' rights along the Mexico-US border). The literature, reviewed below, has developed significantly over the last fifteen years but is marked by important shortcomings. Important questions that need to be addressed include: what is the relationship between political institutions and crossborder culture? Can this culture be created from the "top-down" or is it necessarily a "bottom-up" grassroots process? What accounts for significant changes in political culture?

This article examines water politics along the Mexico-United States (US) border. In global water debates, including those found along the Mexico-US border, many observers have discussed the need to construct or reinforce "water cultures" that would support conservation strategies (Brown et al. 2003; Maganda 2005; Sabet 2008; Walsh 2011). Through an analysis of events that transpired between 2003 and 2010 concerning water distribution in the binational Colorado River Basin, this article contends that a fundamental shift in political culture along the border has occurred. There has been a significant change in cultural dynamics: from political culture, defined as community-based-norms that promote cross-border cooperation in water distribution strategies, to a conceptualization of culture embedded in rationality which acts merely as a filter through which political interests pass. This important change has elevated the role of local leaders in decision-making processes concerning water distribution. Thus, when analyzing the notion of culture in border regions, one must differentiate between general "bi-national political cultures" and more specific "institutional cultures." These terms will be explained in detail below.

The article is divided into four sections. Following this introduction, part two addresses the notion of political culture and its uses in the analysis of political systems. It also discusses the use of "culture" as a conceptual tool in academic and political water debates. Part three then presents empirical research in the shared Colorado River Basin. It examines recent changes in the "border water culture." Finally, part four offers theoretical conclusions that respond to recent claims that there has been a breakdown of the water culture along the Mexico-U.S. border.

\section{The role of culture in border water politics}

This work engages two different bodies of academic literature: one on borders and another concerning water. While some authors, such as Newman (2006), Perkmann (2003), Brunet-Jailly (2005) and Anderson (2001) have attempted to create interdisciplinary "border theories," these different branches of border studies rarely engage in collective dialogue. Instead, Koff (2007) identifies separate discussions that have formed around the themes of 1) multi-level governance, 2) the presumed "borderless world," and 3) the so-called "new regionalism." It is within this third sphere that the notion of emerging "border cultures" is usually addressed. This article contends that the separation between the spheres of border studies is artificial and that "border culture" is as important to multi-level governance or economic regulation as it is to new regionalism. This approach is explained in the following paragraphs that discuss the role of culture in each of the strands of the comparative literature on borders.

\section{The role of culture in border studies}

Whereas traditional analysis of regional integration, especially in the European Union, focused on the political tension between supranational organizations and their member states, recent studies have begun analyzing institutional relationships through the lens of "multi-level governance." This framework, originally proposed by Marks and Hooghe (2001), argues that successful policy implementation, especially in the arenas of regional and social development, is dependant on the activities of local government. The authors describe two types of multi-level governance. Type 1 analyzes the standing relationship between agencies of

\footnotetext{
${ }^{1}$ Dr. Carmen Maganda, Research Associate, Laboratoire de Sciences Politiques, Université du Luxembourg - Campus Walferdange. Bâtiment X, bureau 1.04 B.P. 2/Route de Diekirch L-7220 Walferdange, Luxembourg. Email: carmen.maganda "at" uni.lu. Thankyou to Casey Walsh for translation, and for editing this article. This article is part of a Special Section on "Mexican water studies in the Mexico-US borderlands," edited by Casey Walsh.
} 
general purpose jurisdiction. Conversely, Type 2 multi-level governance is understood as the interaction of public and private local, national, and supranational actors in specific policy processes, such as water distribution, economic development, etc.

The interesting contribution of this literature is its analysis of political interests in local political communities. The authors recognize the fact that efficient policy-making in cross-border regions is dependent on local actors. Moreover, they effectively link separate debates concerning decentralization and supranationalism. Their argument is based on the idea that leaders follow rational interests. Through increased embeddedness in supranational cooperation, local actors free themselves, to a certain extent, from central state authorities. Many argue that this creates challenges to the nation-state from above and below.

In general, this literature has not incorporated "culture" within its remit. As mentioned above, most works are institutional in their approach or they are focused on policy. However, one must ask: what incentives drive the behavior of political actors within the structure of multi-level governance? Generally, the literature in this field points to cross-border political cooperation as a means to effectively address transnational issues (Perkmann 2003; Anderson 2001; Scott 2005). However, is policy efficiency really the motor behind multi-level governance? Recent comparative research suggests that the interests of local political elites more effectively explain political behavior than policy efficiency (Koff 2007). Koff's study of border developments in European and North American communities indicates that cooperation occurs only when local actors on opposite sides of national boundaries can utilize it as political capital. Similarly, scholars of EU trans-border policies have argued that the effectiveness of policy implementation often derives from their worth in terms of political capital (Scott 2005). Thus, in response to the question, "why do individual border actors follow multi-level governance strategies?" one can contend that they are pushed to do so by institutional interests, which are based on local institutional norms. These norms, recognized in traditional political studies by scholars such as Max Weber (1978), Douglass North (1990) and Margaret Levi (1988), introduce the notion of culture into governance because they influence the incentive structures of decision-makers within multi-level governance systems.

A similar argument can be proposed in the second strand of the border literature that focuses on the development of a "borderless world." In this literature, most "border integration" is viewed in terms of crossborder economic cooperation and connecting markets. Few scholars, however, openly engage the question "why does economic interconnectedness take place?" Usually, the so-called borderless world is presented as a sign of globalization rather than a contributor to it. In fact, the foremost proponents of "borderless" politics are not scholars of border communities themselves, but social theorists with interests in international geopolitics (Ohmae 1990; Jacobson 1996; Bauböck 1997). These scholars argue that socio-economic activities are no longer constrained by state borders and transnational networks of economic exchange, information, intellectual exchange, and social mobilization have created competition to the nation-state. However, one could argue the opposite: that these technological and economic transitions have guided a "cultural shift" that has increased incentives for border elites to create cross-border economies. Political economists, such as Rogowski (1989), Frieden (2006) contend that economic competition has been transformed in the post-Fordist era. Whereas previous cleavages divided states or economic classes, they argue that contemporary divisions are based on geographic characteristics (i.e. rural versus urban) or economic sectors (i.e. traditional industry versus high technology), thus decentralizing economic relationships. Obviously, transformed economic relationships influence social ties in border communities.

These social ties are of interest to the third strand of literature in border studies, and the area where most studies of border culture are found. According to recent scholarship on political identities, the deterritorialization of the nation-state has led to the emergence of new ideologies and movements based on ethnicity, language, place of belonging, etc., and the nature of local political organization and culture has significantly affected how border politics function. Studies of nationalist movements (such as the Catalan movement), minority groups (such as Gypsies in Eastern Europe), and stateless nations (such as the Québecois or Basques) have examined the connections between these groups and the global political arena. In his study of pluri-nation states, Keating (2001) has demonstrated that these movements are not necessarily integrated into the institutional architecture of their respective countries. Thus, territorial boundaries are not fundamental for the construction of identity, which decreases the demarcating influence of borders within ethnic debates (see Barany 2002; De Frantz 2007; Bray 2007). In North America, some observers have examined the historical development of cross-border cultures through the presentation of border narratives (Martinez 1996; Bonilla et al. 1998). These studies, like those found in Europe, conceptualize culture in terms of social interaction, "a sense of belonging to a single cross-border community" and they focus on the emergence of cross-border identities and their impact on social mobilization.

\section{The role of culture in water politics}

In addition to the evolving literature on border regions, there are contemporary studies of water politics, especially those focusing on shared river basins. The recent literature has been particularly thorough on the impact of legal agreements and institutional arrangements (Conca 2006; Ingram 1990, 1995; Mumme 2003, 2005; Samaniego López 2006), local political competition for water resources (Brown et al. 2003; Garcia 2005; Maganda 2005; Sánchez 2005), the impact of civil society on water sharing (Bennett 1995; 
Sabet 2008; Walsh 2005, 2011), and the need for education programs concerning water conservation (Vásquez 2002; Monsivais \& Silvan 2006). The role of culture in water issues is generally treated separately from studies of water politics, and is understood in terms of conservation. Subjects that attract attention are institutional programs that promote water savings or create water supervisors/saviors among citizens (Corral Verdugo 2000; Walsh 2011), or the cultural manifestations - such dances, ceremonies, etc- that constitute irrigation traditions (Martínez Saldaña 2005, 2012; Rodríguez 2006). However, like the border literature introduced above, current works on water politics generally fail to integrate governmental, economic and social spheres.

Scholars from each side of the Mexico-US border also have their own distinctive perspectives, and this demonstrates a lack of dialogue across national and linguistic lines. There are many works from U.S. authors on cross-border water management within U.S. and Mexico (with a lack of analysis of water politics in North America: Canada, U.S. and Mexico as an integrated region). This kind of work generally focuses on the impact of regional integration on the management of water resources at the national and supranational levels. ${ }^{2}$ Also, another characteristic of the US literature is the focus on institutional agreements that regulate water distribution between the US and Mexico. Stephen Mumme's work presents valuable analyses of binational water agreements as well as the institutional and local capacities for transboundary water management and environmental policy-making. Helen Ingram and Joachim Blatter point to the need for more integrated and participatory approaches. Similarly, other US authors examine institutional development and political interest representation in transboundary waters governance (McCool 2003; Mumme and Brown 2002; Wilder 2000a; Varady and Milich 1998). The general approach of these works is a "top down" examination of the bi-national water agreements and their (lack of) implementation.

Conversely, the Mexican literature on border water management takes a "bottom up" approach. With a focus on local actors and local practices related to irrigated agriculture and population dynamics, recent studies do not necessarily address the institutional arena (Aboites 2000; Cortéz-Lara 2012; Walsh 2005; and Wilder 2000b). Others have been developing the theme of water as a public service, and treating issues of marginalization and social conflict (Bennett 1995; Mendez 1993; Pombo 2002; Pineda 2002). Only a few authors incorporate analysis of bi-national water management (Bustamante 1999; Fernandez and Carson 2002; Cortéz-Lara 2012; Sánchez 2005). This strand of the Mexican literature is more receptive to cultural approaches to water politics. It is also important to note that because there is very little dialogue between those authors who focus on legal dimensions of water distribution in shared river basins (Conca 2006; Ingram 1995; Mumme 2003) and those scholars who study civil society, grassroots mobilization and noninstitutional competition for water (Berry 1997; Sabet 2008; Walsh 2004), the notion of culture is rarely theorized or utilized in institutional studies.

This article argues that culture as a conceptual tool is valid but its definition in water studies is too narrow. Because of the divisions in the literature on water, that mirror the artificial distinctions found in the border literature presented above, the use of "culture" as a conceptual tool is often also limited to its ideological impact as a system of social norms that dictate both our political beliefs and how we act on them (Sargent 1980). Where culture is utilized in research in Mexico focusing on "new regionalism" for example, it is invoked to explain social capital, defined as the development of interpersonal "trust" in communities. This trust then acts as the basis for political cooperation.

This framework is limited, and culture cannot be viewed as a monolithic construct that affects all parts of local communities equally. This study presents a complex view of political culture that derives from the field of political economy and it contends that is should be applied to all arenas of politics. It argues that the demarcation between the governmental, economic and social spheres that characterizes both contemporary works on border regions and current studies of water politics is artificial. Instead, this contribution to both sets of literature posits that more than one type of political culture exists, and recent events in water policymaking at the Mexico-U.S. border demonstrate a fundamental shift in "border water culture" that reflects changes in the local political landscape of all three spheres: political, economic and social. Consequently, the concept of culture needs to be interpreted more broadly in order to increase its effectiveness in border water studies.

\section{Calculativeness, trust and economic organization in border water politics}

Since 1963, when Gabriel Almond and Sydney Verba published The Civic Culture, scholars have attempted to shed light on the relationship between public attitudes and democratic stability. According to the authors, political culture refers to "attitudes toward the political system and its various parts, and attitudes toward the self in the system" (Almond and Verba 1963: 13). Since its publication, many have attempted to explain why certain attitudes prevail over others (Inglehart 1989) and how public views contribute to, or

\footnotetext{
${ }^{2}$ Studies include publications from environmental centers such as the Water Governance program (part of the UNDP: United Nations Development Programme), the Global International Waters Assessment (GIWA), the International Water Resources Association (IWRA), the Utton Transboundary Resources Center, the Pacific Institute and the North American Congress on Latin America (NACLA), the New Mexico Water Resources Research Institute, or the Water Resources and Policy Group at Udall Center at the University of Arizona, among others.
} 
detract from, the stability of democratic systems (Diamond 1999; Putnam 1976). In general, however, the vision of political culture presented in this literature focuses on collective attitudes that are "taught" to individuals through various socialization processes. Individuals passively receive these views which dictate notions of acceptable and unacceptable behavior.

This approach to the study of political culture dominates the literature on water politics. Many scholars stress the need to develop a political culture of cooperation to work together in bi-national institutions and organizations to address water-related cross-border problems. However, as Sabet (2005) correctly argues, governments are constrained in addressing bi-national policy problems by the limits of their legal jurisdiction. This need is insufficient by itself to produce bi-national civil society collaboration when civil society actors are dependent on government. Sabet's study shows that civil society environmental organizations are also sensitive to domestic political opportunity structures on each side of the border. Thus, the political and legal divisions between the US and Mexico not only limit a bi-national governmental response but also indirectly limit civil society responses.

An alternative vision of political culture has received much attention in classical democratic debates, even though it has largely been ignored in the literature on water politics. Economic approaches to culture focus squarely on what Oscar E. Williamson (1993) describes as "calculativeness" - a tendency to quantify, measure or formalize. In this sense, economics not only represents markets of exchange, but also refers to a methodology based on rational choices. Like the definitions presented above, Williamson formulates a notion of culture that is composed of public values and norms. However, he argues that these attitudes can only be viewed as limits to the behavior of rational individuals. Thus, culture does not affect individual action because of inherent beliefs. Instead, it creates externalities that affect one's perception of costs and benefits. Of course, this approach radically changes our perceptions of "trust" and "cooperation" which are embedded in rational interest rather than normative behavior.

This point is significant in water discussions because the type of culture displayed seriously affects how cross-border cooperation is created. For example, cross-border water sharing is often lauded as ethical behavior because it is based on equitable distribution and it aims to guarantee future supplies through sustainable policies. It is often argued that "political culture," "trust," and "cooperation" (Mumme 2003; Sánchez Munguia 2005) are fundamental bases for the stability of such strategies. However, one must ask, are ethics strictly normative? Can they be based on rationality? Radu Vranceanu (2005: 5) writes:

... No suitable response to the economic drawbacks of the capitalist system can emerge if the ethical perspective is disregarded; unfortunately, in the past, decision-makers at various hierarchical levels have all too often tended to neglect that dimension. To some extent, this may be connected to their general education, which chiefly targets effectiveness. Related to this fundamental goal of waste reduction, economics - seen as a theory of choice - plays a critical role in the global ideology of capitalism.

Does the absence of such strategies signify a lack of political culture? Vranceau lays out different visions of ethical behavior that have developed in the history of political thought. For example, he argues that whereas Aristotle and St. Thomas Aquinas highlighted the notion of moral virtue, utilitarian philosophers such as Jeremy Bentham and John Stuart Mill utilized a more economic approach in their definitions, which focused on the largest balance of good over bad for all agents.

The most important difference between these two approaches relates to decision-making. Traditional views of culture focus on collective behavior and its institutional bases. For example, Robert Putnam has argued that individual participation in civic organizations strengthens cultural bonds of cooperation, solidarity and trust. Conversely, economic approaches to culture and cooperation focus on rational decisionmaking, leadership and elite behavior more than grassroots movements and collective action. Thus, I argue that the current emphasis on elite decision-making in the field of border water politics suggests a fundamental shift in the type of culture that predominates, from traditional grassroots cooperation to economic rationality and policy efficiency. This transformation has occurred because, as the border literature presented above correctly states, nation-states no longer control flows across their borders. Thus, economic markets have expanded, cross-border identities have emerged, and local governmental actors have engaged in new forms of transnational cooperation. These changes, which reinforce each other, have altered norms and attitudes in border regions by shifting both types and uses of political power. Thus, culture has become less collective and more fragmented as it has been infused into a system based on rationality. Whether this new form of culture is ethical, remains to be seen. These issues are the focus of empirical research on the bi-national Colorado Basin. 


\section{Border water culture in the Colorado River shared basin}

The literature on border politics presented above acknowledges important shifts in the economic and political systems of border regions. However, one element is absent from most of the studies in this rich body of literature: power. The uses and types of power found in border regions are not completely ignored by authors of border politics (Koff 2007; Cornelius 2005). However, the artificial separation in the literature between informal politics and institutional arrangements has created an incomplete analysis of power in border areas.

Water politics along the Mexico-U.S. border have been historically characterized by formal competition and informal cooperation. The conflictive sharing of water sources by Mexico and the U.S. has has created tensions in the larger bi-national relationship. At the same time, local actors have traditionally cooperated on a daily basis to solve water scarcity issues that affect both sides of the border. This collaboration had its roots in collective norms and common interests that overcame the political tensions that characterized the national political arena (Walsh 2004). This work examines recent developments in local binational relationships in the shared Colorado River Basin.

\section{Bi-national water arrangements concerning the Mexico-US Border}

The rich scholarship that examines water politics along the 3,200 km Mexico-U.S. border has clearly illustrated the demographic and economic growth in this region, the need for increased water supplies to sustain this advancement, and the political challenges that leaders face to guarantee necessary water resources. The largest challenge is constructing policy solutions at the bi-national level that respond to the priorities of both states. Numerous themes characterize the bi-national water agenda because debates concerning shared water bases have historically been intense (Ingram 1995). On both sides of the border, cities and rural communities are experiencing unprecedented tensions over limited water resources due to the drought that has marked the region's climate over recent years (Gleick 2002). Authorities in the border region must confront an unequal distribution of water as well as inadequate hydraulic resources. Mexico depends on the same water as the U.S. States of California, Arizona, Nevada and Texas. These concrete problems work against the spirit of regional integration. Since the signing of the North American Free Trade Agreement (NAFTA) in 1992, the Mexico-U.S. border has been a high priority on the political agendas of both countries, thus reducing the sovereignty of both states in terms of decision-making in the region (Mumme 2003; Mumme and Brown 2002). While decisions are made nationally, their impacts are bi-national and this increases the need for integrated cross-border local political systems (Liverman et al.1999). In terms of water management, for example, the distribution of this precious resource is not always visible to citizens, who do not understand the long-term problems that their actions cause for the sustainability of water supplies.

The academic literature on bi-national Mexico-US water agreements (see Table one) is very detailed. Water diplomacy in the region dates to March 1, 1889 when a Commission was created to manage binational water resources. The Commission's descendant, the International Border Water Commission (IBWC/CILA) continues to promote bi-national water agreements and it is the institutional guardian of the major legal instrument that governs water distribution along the Mexico-US border: the 1944 Treaty for Utilization of Waters of the Colorado and Tijuana Rivers and of the Rio Grande. The Commission's importance derives from the incomplete nature of the 1944 treaty. While this agreement assigns specific quantities of surface water, it does not mention the quality of the water nor the distribution of groundwater and its does not address long-term drought, which contributed to the increase in Mexico's water debt along the northeast part of the border during the late 1990s and early 2000s (Nitze 2002). Thus, the IBWA/CILA must intervene in these gray areas as the main bi-national institution responsible for water management in the border region.

The problem with the IBWA/CILA's role in bi-national water politics is directly related to the issue of "water culture" along the border. This governing body has never been well-known publicly, even though it has been involved in every major decision concerning bi-national water resources since 1944. In fieldwork conducted between 2002 and 2004, I found that most inhabitants of the border region did not know of its existence or its responsibilities. Moreover, the IBWC/CILA has been accused of a range of alleged institutional deficiencies (Mumme 2005), starting with its complex supranational institutional structure. It operates under the Mexican and US foreign ministries rather than under environmental or water authorities from the two countries. As a result, access points for citizen participation are restricted. The IBWC seems to produce opacity in border water politics, rather than bi-national cooperation. 


\begin{tabular}{|c|c|c|c|}
\hline Year & Event & Objectives & Major Structural Problems \\
\hline 1848 & $\begin{array}{l}\text { Treaty of Guadalupe } \\
\text { Hidalgo }\end{array}$ & $\begin{array}{l}\text { Definition of the international } \\
\text { boundary }\end{array}$ & \\
\hline 1889 & $\begin{array}{l}\text { Convention that created the } \\
\text { International Boundary } \\
\text { Commission }\end{array}$ & $\begin{array}{l}\text { Observance of the rules of the } \\
\text { Boundary Treaties and the } \\
\text { Convention concerning the } \\
\text { changes of course in the } \\
\text { international river }\end{array}$ & \\
\hline 1944 & $\begin{array}{l}\text { Treaty for Utilization of } \\
\text { waters of the Colorado and } \\
\text { Tijuana Rivers and of the } \\
\text { Rio Grande and the creation } \\
\text { of the International } \\
\text { Boundary and Water } \\
\text { Commission }\end{array}$ & $\begin{array}{l}\text { Allocated waters of the } \\
\text { international rivers between the } \\
\text { two countries and extended the } \\
\text { functions of the IBWC }\end{array}$ & $\begin{array}{l}\text { Only addresses quantities of } \\
\text { surface water, no mention of } \\
\text { "extraordinary drought", } \\
\text { groundwater or water quality. } \\
\text { Surface water quantities fixed } \\
\text { since } 1944 \text { with no update }\end{array}$ \\
\hline 1983 & $\begin{array}{l}\text { Agreement for the } \\
\text { Protection and Improvement } \\
\text { of the Environment in the } \\
\text { Border Area (La Paz } \\
\text { Agreement) }\end{array}$ & $\begin{array}{l}\text { Provided formal guidelines for the } \\
\text { bi-national participation of various } \\
\text { levels of government in the design } \\
\text { and implementation of trans- } \\
\text { boundary environmental solutions } \\
\text { by specific work groups }\end{array}$ & $\begin{array}{l}\text { Reinforced national regulation of } \\
\text { water issues as border remained } \\
\text { low priority. It has big aspirations } \\
\text { for bi-national cooperation but } \\
\text { commits no funds and delegates } \\
\text { no power }\end{array}$ \\
\hline 1992 & $\begin{array}{l}\text { Release of the Integrated } \\
\text { Environmental Plan for the } \\
\text { US-Mexican Border Area } \\
\text { (IBEP) }\end{array}$ & $\begin{array}{l}\text { Strengthened enforcement of } \\
\text { environmental laws, increased } \\
\text { cooperative planning, completed } \\
\text { the expansion of wastewater } \\
\text { treatment facilities }\end{array}$ & $\begin{array}{l}\text { Lacked institutional framework } \\
\text { necessary to effectively carry out } \\
\text { goals }\end{array}$ \\
\hline 1993 & $\begin{array}{l}\text { Creation of the Border } \\
\text { Environment Cooperation } \\
\text { Commission (BECC) and } \\
\text { the North American } \\
\text { Development Bank } \\
\text { (NADBank) }\end{array}$ & $\begin{array}{l}\text { Assisted communities on both } \\
\text { sides of the border in coordinating } \\
\text { and carrying out environmental } \\
\text { infrastructure projects }\end{array}$ & $\begin{array}{l}\text { Dominated by the US due to } \\
\text { discrepancies in the distribution of } \\
\text { funding. Commodifies water } \\
\text { through managerialist discourse }\end{array}$ \\
\hline 1996 & $\begin{array}{l}\text { Release of Border XXI } \\
\text { Program }\end{array}$ & $\begin{array}{l}\text { Promoted sustainable } \\
\text { development in the border region }\end{array}$ & $\begin{array}{l}\text { It suffered from deficiencies in } \\
\text { public participation and public } \\
\text { access. It was severely under- } \\
\text { funded }\end{array}$ \\
\hline 2002 & $\begin{array}{l}\text { Border 2012: US-Mexico } \\
\text { Environmental Program }\end{array}$ & $\begin{array}{l}\text { Addressed environmental and } \\
\text { environmentally related health } \\
\text { problems on the Mexico/US } \\
\text { Border, in partnership with official } \\
\text { environmental agencies }\end{array}$ & $\begin{array}{l}\text { In progress. Evaluation to be } \\
\text { determined }\end{array}$ \\
\hline
\end{tabular}

Table 1. Principal events in the evolution of water management between the U.S. and Mexico. Source: Van Schoik, 2003: p.6. Note: the year 2002 and Major Structural Problems column are author's additions.

The cultural problems of water management along the Mexico-US border are primarily related to citizen activity. In fact, bi-national cooperation in civil society surrounding water issues exists (Sabet 2002), and so the main cultural difficulties in the region are directly tied to multi-level governance and the aforementioned "borderless world." In terms the first sphere of border studies, it is interesting to note that many management decisions are significantly affected by institutional norms. Since the inception of the IBWC/CILA, this Commission's authority has faced one major limitation: it can only act in questions that directly affect the international boundary that separates Mexico from the US (Mumme and Brown 2002). Thus, like officials in many supranational institutions (Hix 1999), the members of the Commission have been significantly influenced by institutional norms pushing integration in order to increase its sphere of influence. This is absolutely necessary from the Commission's point of view because its work has recently been criticized as antiquated due to its limited powers. In fact, many of its projects and suggestions have not been followed by local border authorities or financed by the national governments. Moreover, it has been criticized for being slow and overly bureaucratic. 
It is important to note the formal and informal dimensions of border water politics along the MexicoUS divide. The 1944 Treaty does not address numerous important questions, such as the promotion of environmental values, the domestic distribution and urban consumption of water, agricultural uses of water and protection for border communities from floods and droughts. For this reason, water management has been traditionally characterized by informal agreements between local officials that addressed the needs of communities on both sides of the border. Many observers attributed such cooperation to the existence of shared norms in border communities concerning the need to maximize the sustainability of water resources (Bennett 1995; Michel 2000). The notion of culture undergirding this interpretation is tied to trust, shared values, and community, and local officials cooperated across borders in order to maximize water efficiency.

Following this argument, then, one could state that the recent decision to pave the All-American Canal and to prevent groundwater from seeping into Mexico signifies a breakdown of the border water culture in Southern California, because it demonstrates self-interested behavior. Is this actually the case? By examining this specific case, which concerns the bi-national Colorado River Basin, I argue that the behavior of local water authorities does not demonstrate a cultural breakdown. Rather it is a reinforcement of institutional norms through the creation of a "borderless world." As leaders work to expand globalized urban economies, they pursue the water resources necessary to achieve their goals. Whereas the regional economies that characterized the Mexico-US border facilitated cooperation in water management, the economic expansion promoted by the North American Free Trade Agreement (NAFTA) broke economic partnerships which created less incentive for collaboration in the field of water distribution. This point will be explained in detail below.

\section{Water management in the Colorado Basin and border water culture}

The Colorado River and its tributaries compose a basin of $632,000 \mathrm{~km}^{2}$ (244,017 square miles), of which 32,000 km² (12,355 square miles) comprises the Colorado River Delta. The water from the Colorado River is used by the upper basin states (Colorado, New Mexico, Utah and Wyoming), the lower basin states (Arizona, California and Nevada) and Mexico. Dams constructed from 1909 to1935 changed the character of the river from a warm, turbulent, and sediment-filled channel to a cold, regulated, and clear one (Cohen 2002). Drained by seven states, the river becomes a muddy trickle when it reaches Mexico. The Environmental Protection Agency (EPA) estimates that by 2020 about 38 million residents of the lower basin will be use the Colorado's water, and the population dependent on this river will increase by 91\% (E.P.A. 2002). Of course, such population increases will add immense pressure to the river's water supplies and competition for these resources will increase dramatically.

The administration of the Colorado's water resources has been based on the "Law of the River" which is a collection of legislation, judicial decisions, and other documents that have been collected since the middle of the 19th century to regulate the use of its waters. Implementation of these laws gives priority to those who arrived first. A complex system of urban water and irrigation districts became the framework for decision-making related to an always more vulnerable resource. Management has been further complicated by over-allocation of water, as the river's upper basin states, primarily Utah and Colorado have yet to fully develop their shares, which has enabled lower basin states, particularly California, to use more than their formal entitlement. According to the Metropolitan Water District (the main water authority for metropolitan areas located in Southern California), California's annual use of water resources from the Colorado River has varied between 5.55 and $6.41 \mathrm{Bm}^{3}$ over the last decade, even though the state only has the right to $5.43 \mathrm{Bm}^{3}$. This is possible because California has the right to purchase unused water resources from the other US states.

Most of the recent literature that focuses on water management in the Colorado River Basin addresses policy issues, economic questions or ecological impacts (Carle 2000; Cohen 2002; Getches 2003). This article contends that water management in the basin involves cultural issues as well. In fact, the Law of the River has created a system of water management that has reinforced norms of acceptable behavior for officials operating within it. In the specific case of Southern California, urban authorities have purchased water from other areas for many years and they have spent a great deal of money on expensive water transfers that have supported the area's dynamic demographic and economic growth. Hence, parts of California and Tucson, Arizona have grown quickly, importing water from distant locations to meet their needs. Unlike, the IBWC/CILA, water officials have worked within institutional norms aimed at promoting growth rather than a system designed to maximize policy efficiency.

For years these systems operated side by side with little difficulty. The recent conflict between the IBWC/CILA and local authorities however, has been created by recent transformations in the region's economy. Traditionally, water in the western US developed under institutions designed to encourage settlement and consumptive off-stream use. Irrigation made Imperial Valley in California (US) and the Mexicali Valley in Baja California (Mexico) centers of development. Moreover, the cities of San Diego (US) and Tijuana (Mexico) were relatively small and did not place heavy burdens on local water supplies. In recent years since the inception of NAFTA, the economic relationships in the border region have changed dramatically, and this has significantly affected the uses of water resources.

NAFTA's impact on the regional economy is especially visible in the San Diego and Tijuana metropolitan areas. The San Diego-Tijuana area represents the busiest border in the world with about seventy 
million crossings each year. The region's economy is worth US\$100 billion, which ranks it as the thirty-sixth largest economy in the world. Its population has skyrocketed to over four million inhabitants, 2.8 million of whom reside in San Diego and 1.2 million of whom live in Tijuana (Blatter 2004). Since 1993, when NAFTA was implemented both of these cities experienced major transformations of their economic foundations. In San Diego, local officials effectively planned and negotiated a shift to a "New Economy" based on high technology. They identified nine clusters in high-tech fields, including biomedical production, biotechnology and pharmaceuticals, computer software, wireless telecommunications, electronic and computer manufacturing, business services, financial services, defense and transportation manufacturing, and environmental technology. This shift fundamentally changed the focus of the San Diego economy from one based on regional markets to an economy oriented towards international exports.

Similarly, Tijuana has greatly benefited from NAFTA. The city has an official growth rate of 6.9 percent each year. Its population has increased from 740,000 in the late 1970s to 1.3 million in 2000. Actually, local planners expect growth to continue at even higher rates, doubling the population again by 2020 (Tijuana Economic Development Corporation 2005). This demographic expansion has significantly contributed to the development of the local maquiladora economy. The local Chamber of Commerce has utilized high rates of education to lure companies such as SONY, Panasonic, and Samsung to the area. Tijuana has one of the highest concentrations of specialized workers in Mexico and the highest concentration of maquiladoras in the country (Tijuana Economic Development Corporation 2005). Of course, the city's economic growth has also been aided by its geographic position. Tijuana has proclaimed itself "the television capital of the world" because of the strong presence of maquiladoras. These televisions, radios, stereos, etc. represent 48.6 percent of the all exports from Mexico with a value of US\$18,680 million (Erie 1999).

San Diego and Tijuana could be considered examples of "the borderless world." However, this case is especially interesting for the way these cities, especially San Diego, obtained their positions in the global economy. Most of the "borderless world" studies discuss the inability of states to control expanding financial markets. Instead, this border area demonstrates that these expanding markets are the fruit of state planning, especially in water politics. Of course, such economic growth would not be possible without sufficient water resources. As stated above, water in the Mexico-US border region was traditionally targeted for agricultural settlements, and the city of San Diego began importing water from unused sources more than one hundred years ago as the city began to grow. This tradition developed and local leaders found new, distant sources for their water needs as the region's economy expanded. These local elites have enough political power (due to San Diego's financial importance to the state) to negotiate investments, build dams, and get the required allocation of water. Currently, anywhere between 75 to 90 percent of San Diego County's water is imported.

Because San Diego imports so much water, the city has attempted to diversify its sources, which has forced leaders to re-evaluate agricultural-urban relationships in water distribution. Since the late 1980s, local officials have attempted to purchase surplus water supplies from the neighboring Imperial Irrigation District (IID). Despite public opposition, a 2003 agreement guaranteed the transfer of up to $246 \mathrm{Mm}^{3}$ per year of IID water. Also, San Diego's water authorities agreed to line both the All-American and Coachella canals with cement to reduce seepage, with the State of California obligated to pay up to US\$235 million for the modifications. In return, the San Diego Water Authority will receive $95 \mathrm{Mm}^{3}$ of "saved" water per year from the All-American Canal for 110 years.

The problem with this agreement is that it will adversely affect the Mexicali Valley on the Mexican side of the border. Mexicali is now the third-largest Mexican border city, with a population close to one million. The filtered groundwater replenished from the AAC had the highest quality on the northeast side of the Mexicali Valley. It has traditionally been used to support high-value agricultural products such as table grapes and onions, but the lining of the AAC will greatly limit groundwater recharge into Mexico and reduce water availability and quality for those crops. This decision, made in the knowledge of the probable negative consequences to Mexicali's agriculture, has led many observers to conclude that the previously cooperative border water culture has broken down. This conclusion needs further exploration. In fact, public opposition to the 2003 San Diego-IID water agreement was strong on both sides of the border. A border water culture still exists amongst civil society and it is as active as ever. The 2003 San Diego-IID water agreement does not necessarily demonstrate a breakdown of bi-national border water culture, but rather a clash of institutional cultures that dictated the decision-making processes of local water managers.

\section{Conclusion: calculativeness and culture in border water politics}

Often, the term "political culture" is utilized in water politics to explain why citizens do not appreciate water resources or scarcity, and to make arguments about what needs to be done to promote changes in public attitudes towards water. The recent events in water politics along the Mexico-US border demonstrate that the prevailing use of this term must be questioned. In this dry area of North America, citizens are aware of the amount of water utilized for economic growth in the area, especially since the region has experienced droughts in recent years. Moreover, protests by different groups in civil society against the San Diego-IID water agreement indicates that many care about the equitable distribution of water supplies. The deal went 
through despite the negative public reaction, and San Diego is in the process of lining the two canals in order to guarantee future water supplies in the metropolitan area.

What is the significance of this agreement? Does it merely show that economic rationality and shortsighted decision-making have won out over years of informal cooperation? This article argues that even though economic considerations are the bases of water decision-making in the area, there were important cultural forces at work in local water management strategies that led to the 2003 agreement. Firstly, local water authorities followed a tradition that has lasted over one hundred years: they found water to import to support the city's needs. But the deal with IID authorities is not just a result of economic considerations. The city has long enjoyed autonomy in water management because its relative wealth has brought political power - and this power facilitates water imports. The behavior of city officials illustrates a political culture within San Diego's water authority with two strong features: 1) the city's political autonomy must be maintained; and 2) it is local authorities, rather than national or bi-national ones, who decide about water distribution in the area even when the effects of decisions concerning water resources are bi-national.

Secondly, the reaction of IBWC/CILA to the 2003 San Diego-IID agreement also reflected a particular institutional culture. The Commission sees itself as the real arbiter of water distribution conflicts in the area. However, it is highly bureaucratic and there is little transparency in its daily activities. For these reasons, concerned citizens on both sides of the border were unable to access this institutional mechanism and to request intervention until it was too late. Moreover, the Commission's reliance on the 1944 Treaty weakened its position against the local authorities because it has no incidence in groundwater debates.

For these reasons, I suggest that the notion of political culture must be addressed more specifically in border water debates. Of course, citizen participation and understanding public attitudes towards water are both important. But space must be made to view culture as institutional norms that guide the behavior of public officials. Calculativeness, based on economic rationality, follows incentive structures. These structures, as Williamson (1993) noted, are not all economic or political in nature. In many cases they are cultural, as norms limit acceptable choices available to decision-makers. In the case of public officials, especially those working in water authorities, these norms are often transmitted by the administrative bodies themselves. Thus, the concept of border water culture must be expanded to include institutional considerations.

\section{References}

Aboites Aguilar, L. 2000. Demografía histórica y conflictos por el agua. Dos estudios sobre 40 kilómetros del río San Pedro, Chihuahua. Mexico: CIESAS.

Almond, G. and S. Verba. 1963. The civic culture. Princeton, N.J.: Princeton University Press.

Anderson, J. 2001. Theorizing state borders: 'politics/economics' and democracy in capitalism. CIBR working papers in border studies CIBR/WP01-1.

Bauböck, R. 1997. Citizenship and national identities in the European Union. Cambridge: Harvard Law School.

Barany, Z. 2002. The East European Gypsies: regime change, marginality, and ethnopolitics. Cambridge: Cambridge University Press.

Bennett, V. 1995. The politics of water: urban protest, gender, and power in Monterrey, Mexico. Pittsburgh: University of Pittsburgh Press.

Berry, K. 1997. Of blood and water. Journal of the Southwest 39(1): 79-111.

Bonilla, F. et al., (eds.) 1998. Borderless borders. U.S. Latinos, Latin Americans, and the paradox of interdependence. Philadelphia: Temple University Press.

Blatter, J. 2004. From 'spaces of place' to 'spaces of flows'? Territorial and functional governance in crossborder regions in Europe and North America. International journal of urban and regional research 28(3): 536.

Blatter, J. and H. Ingram, eds. 2001. Reflections on water: new approaches to transboundary conflicts and cooperation (American and comparative environmental policy). Cambridge, MA: The MIT Press.

Bray, Z. 2007. Boundaries in a 'borderless' Europe: European integration and cross-frontier cooperation in the Basque country. In H. Koff, (ed.) Deceiving (dis)appearances: analyzing current developments in European and north American border regions. Brussels: Presses Interuniversitaires Europénnes/Peter Lang.

Brown, C., R. Wright, N. Lowery, and J.L. Castro. 2003. Comparative analysis of transborder water management strategies: case studies on the United States - Mexico border. In S. Michel (ed.) The USMexico border environment: bi-national water management planning. San Diego, CA: San Diego State University Press.

Brunet-Jailly, E. 2005. Theorizing borders: an interdisciplinary perspective. Geopolitics 10: 633-649. 
Bustamante Redondo, J. 1999. La comisión internacional de límites y aguas entre México y los Estados Unidos. Sus orígenes y su actuación hasta 1996. Ciudad Juárez, Mexico: Universidad Autónoma de Ciudad Juárez.

Carle, D. 2000. Water and the California dream: choices for the new millennium. San Francisco: Sierra Club Books.

Cohen, M. 2002. Managing across boundaries: the case of the Colorado River delta. In P. Glieck (ed.) The world's water. Washington, DC: Island Press. Pp. 133-148.

Conca, K. 2006. Governing water: contentious transnational politics and global institution building. Camkbridge MA: The MIT Press.

Corral Verdugo, V. 2000. La cultura del agua en Sonora: un estudio empírico de los determinantes con textuales e individuales del ahorro del liquido. Estudios sociales 19: 9-31.

Cornelius, Wayne. 2005. Mexicans would not be bought or coerced. In G. M. Joseph and T. J. Henderson (eds.) The Mexico reader: history, culture, politics. Durham, NC: Duke University Press, pp. 684-686.

Cortéz-Lara, A. Forthcoming (2012). No longer strong social cohesion: lessons from two transboundary water conflicts in the Mexicali Valley, Mexico. Regions \& cohesion 2(2).

De Frantz, M. 2007. Nationality politics at Austria's eastern border: the region of Burgenland. In H. Koff (ed.) Deceiving (dis)appearances: analyzing current developments in European and North American border regions. Brussels: Presses Interuniversitaires Europénnes/Peter Lang.

Diamond, L. 1999. Developing democracy: toward consolidation. Baltimore: The Johns Hopkins University Press.

Erie, S. 1999. Toward a trade infrastructure strategy for the San Diego/Tijuana region. http://www.sandiegodialogue.org/papers/infrastructure/infra.html [accessed June 2012].

Fernandez, L. and R.T. Carson (eds.). 2002. Both sides of the border: transboundary environmental management issues facing Mexico and the United States. Dordrecht and Boston: Kluwer Academic Publishers.

Frieden, J. 2006. Global capitalism: its rise and fall in the twentieth century. New York: W.W. Norton.

Garcia Acevedo, M. R. 2005. Mirando a través del canal. Reflexiones sobre imágenes y políticas sobre el agua en Estados Unidos de America. In V. Sánchez Munguía (ed.), El revestimiento del Canal Todo Americano ¿competencia o cooperación por el agua en la frontera México-Estados Unidos? Tijuana, Mexico: El Colegio de la Frontera Norte \& Plaza y Valdés. Pp. 153-188.

Getches, D. H. 2003. Water management in the United States and the fate of the Colorado River delta in Mexico. United States-Mexico Law Journal 11: 107-113.

Glieck, P. (ed.). 2002. The world's water. Washington, DC: Island Press.

Hix, S. 1999. The political system of the European Union. New York: St. Martin's.

Inglehart, R. 1989. Culture shift in advanced industrial society. Princeton: Princeton University Press.

Ingram, H. 1995. Divided waters: bridging the U.S.-Mexico border. Tucson: University of Arizona Press. - 1990. Patterns of politics in water resource development. Albuquerque: University of New Mexico Press.

Jacobson, D. 1996. Rights across borders: immigration and the decline of citizenship. Baltimore: Johns Hopkins University Press.

Keating, M. 2001. Plurinational democracy: stateless nations in a post-sovereignty era. Oxford: Oxford University Press.

Koff, H. 2007. Deceiving (dis)appearances: analyzing current developments in European and North American border regions. Brussels: Presses Interuniversitaires Europénnes/Peter Lang.

Levi, Margaret. 1988. Of rule and revenue. Berkeley, University of California Press.

Liverman, D.M., R. Varady, O. Chávez, and R. Sánchez, 1999. Environmental issues along the U.S.-Mexico border - drivers of changes and the response of citizens and institutions. Annual Review of Energy and Environment 24: 607-643.

Maganda Ramírez, C. 2005. Collateral damage: how the San Diego-Imperial Valley water agreement affects the Mexican side of the border. Journal of Environment and Development 14(4): 486-506.

Marks, G. and L. Hooghe. 2001. Multi-level governance and European integration. Boulder, CO: Rowman \& Littlefield.

Martinez, O. 1996. U.S.-Mexico borderlands: historical and contemporary perspectives. Wilmington, DE: Jaguar Books.

Martínez Saldaña, T. 2005. El agua y cultura en la frontera norte: México-USA. La cuenca del Río GrandeRío Bravo. Cuicuilco 35: 11-35.

Martínez Saldaña, T. 2012. Water rituals on the Bravo/Grande River: a transnational political and ecological inheritance. Journal of Political Ecology 19: 57-69. 
McCool, D. 2003. Evolving political institutions: A new water policy and its impact on the border region. In S. Michel (ed.), The U.S.-Mexican border environment : binational water management planning. SCERP Monograph Series, no. 8. San Diego, CA : San Diego State University Press.

Mendez, E. 1993. La distribución del agua en Tijuana como factor de marginalidad urbana. Frontera y Medio Ambiente 5: 111-135.

Michel, S. 2000. Defining hydrocommons governance along the border of the Californias: a case study of transbasin diversions and water quality in the Tijuana-San Diego metropolitan región. Natural Resources Journal 40(4): 931-972.

Monsiváis, A. and L. Silván. 2006. Youth and education for sustainability on the border: imagining the future citizens of Baja California. In J. Clough-Riquelme and N. Bringas Rábago (eds.) Equity and sustainable development. Reflections from the U.S.-Mexico border. San Diego, CA: Center for USMexican Studies, University of California San Diego.

Mumme, S. and C. Brown. 2002. Decentralizing water policy on the US - Mexico border. In R. Melville and S. Whiteford (eds.) Protecting a sacred gift: water and social change in Mexico. San Diego: Center for U.S.-Mexican Studies, University of California San Diego.

Mumme, S. 2003. Revising the 1944 water treaty: reflections on the Rio Grande drought crises and other matters. Journal of the Southwest 45(4): 649-70.

Mumme, S. and D. Lybecker 2005. El Canal Todo Americano: perspectivas de la posibilidad de alcanzar un acuerdo bilateral. In V. Sánchez Munguía (ed.) El revestimiento del canal todo Americano. Competencia o cooperación por el agua en la frontera México-Estados Unidos? Tijuana and Mexico City: El Colegio de la Frontera Norte and Plaza y Valdes. Pp. 217-245.

Newman, D. 2006. The lines that continue to separate us: borders in our 'borderless' world. Progress in Human Geography 30(2): 1-19.

Nitze, W. 2002. Meeting the water needs of the border region: a growing challenge for the United States and Mexico. Center for Strategic and International Studies (CSIS), Policy Papers on the Americas 13(1).

North, D. 1990. Institutions, institutional change and economic performance. New York: Cambridge University Press.

Ohmae, K. 1990. The borderless world. New York: Harper Collins.

Perkmann, M. 2003. Cross-border regions in Europe. Significance and drivers of regional cross-border cooperation. European Urban and Regional Studies. 10(2): 153-171.

Pineda, N. 2002. Water supply performance, policy and politics on Mexico's northern border. In R. Melville and S. Whiteford (eds.) Protecting a sacred gift: water and social change in Mexico. San Diego: Center for U.S.-Mexican Studies, University of California San Diego.

Pombo, O. 2002. Pobreza, agua y condiciones sanitarias en la frontera norte. Tijuana: El Colegio de la Frontera Norte.

Putnam, R. D. 1976. The comparative study of political elites. Englewood Cliffs, NJ: Prentice-Hall.

Rogowski, R. 1989. Commerce and coalitions. Princeton: Princeton University Press.

Sabet, D. 2008. Nonprofits and their networks: cleaning the waters along Mexico's northern border. Tucson: University of Arizona Press.

Samaniego López, M.A. 2006. Ríos internacionales entre México y Estados Unidos. Los tratados de 1906 y 1944. México: El Colegio de México and Universidad Autónoma de Baja California.

Sánchez Munguía, V. 2005. Contexto e implicaciones para la solución de un problema binacional complejo: el revestimiento del Canal Todo Americano. In V. Sánchez Munguía (ed.), El revestimiento del Canal Todo Americano. ¿Competencia o cooperación por el agua en la frontera México-Estados Unidos? Tijuana,Mexico: El Colegio de la Frontera Norte and Plaza y Valdés. Pp. 247- 272.

Sargent, L. 1990. Comparative political ideologies: a reader. Boston: Brooks/Cole Publishing Company.

Sassen, S. 1998. Globalization and its discontents. New York: New Press.

Scott, J. 2005. Cross border regionalisation in an enlarging E.U.: Hungarian-Austrian and German-Polish cases. In H. Koff (ed.) Deceiving (dis)appearances: analyzing current developments in European and North American border regions. Brussels: Presses Interuniversitaires Europénnes/Peter Lang.

Tijuana Economic Development Corporation. 2005. City of Tijuana. http://www.tijuana-edc.com/. [accessed June 2012].

Van Schoik, D.R. 2003. Executive summary. Opportunities, costs, benefits and unintended consequences: secure and sustainable water by 2020. In Michel, S. (ed). The U.S.-Mexican border environment: binational water management planning. SCERP monograph series \#8, San Diego: San Diego State University Press.

Varady, R. and L. Milich. 1998. Managing transboundary resources: lessons from river-basin accords. Environment 40(8): 10-41. 
Vásquez, O. 2002. Education in a global age. An inter-California strategy for the Tijuana-San Diego region. Frontera Norte 14: 22-46.

Vranceanu, R. 2005. The ethical dimension of economic choices. ESSEC Working Papers DR05001.

Walsh, C. 2004. 'Aguas broncas': the regional political ecology of water conflict in the Mexico-U.S. borderlands. Journal of Political Ecology 11: 43-58.

- 2005. Región, raza y riego: el desarrollo del norte mexicano, 1910-1940. Nueva Antropología 19: 53-73.

- 2011. Managing urban water demand in neoliberal northern Mexico. Human Organization 70(1): 5462.

Weber, M. 1978. Selections in translation. W. G. Runciman (ed.). New York, Cambridge University Press.

Wilder, M. 2000a. Border farmers, water contamination, and the NAAEC environmental side accord to NAFTA. Natural Resources Journal 40(4): 873-94.

- 2000b. The "new culture" of water and the communal farmers of the Yaqui Valley, Sonora. Estudios Sociales 10: 63-97.

Williamson, O. 1993. Calculativeness, trust, and economic organization. Journal of Law and Economics 36: 453-86.

\begin{abstract}
This articles examines water politics and the creation of a "transborder water culture" along the western end of the Mexico-U.S. border. In global debates over water, some observers see the need to construct water "cultures" that reinforce conservation strategies, as well as transnational political cooperation. This article discusses events related to the distribution of water in the bi-national Colorado River watershed from 20032010. The article argues that a fundamental change has occurred in the concept of water culture along that border, from an idea of political culture defined as community norms that promote transborder cooperation in the strategies of water distribution, to an idea of culture as rationality that serves as a filter through which pass the political interests of individuals. This change has elevated the role played by local leaders in the process of decision-making about water distribution. An analysis of water culture in the Mexico-US borderlands must differentiate between general "binational political cultures", and specific "institutional cultures."
\end{abstract}

Key Words: Mexico-U.S. border, transborder water culture, political culture, Colorado River watershed

\title{
Resumé
}

Cet article examine la politique de l'eau et la création d'une «culture de l'eau transfrontalière» le long de l'extrémité ouest de l'américano-mexicaine frontière. Dans les débats mondiaux sur l'eau, certains observateurs voient la nécessité de construire «cultures de l'eau» qui renforcent les stratégies de conservation, ainsi que la coopération transnationale politique. Cet article traite des événements liés à la distribution de l'eau dans le bassin versant binational du fleuve Colorado de 2003 à 2010. L'article fait valoir qu'un changement fondamental s'est produit dans le concept de culture de l'eau le long de cette frontière. Une idée de la culture politique définie en tant que normes communautaires qui favorisent la coopération transfrontalière dans les stratégies de distribution de l'eau, s'est déplacée vers une idée de la culture comme la rationalité qui sert comme un filtre, à travers lequel passent les intérêts politiques des individus. Ce changement a élevé le rôle joué par les dirigeants locaux sur la distribution de l'eau. Une analyse de la «culture de l'eau» dans les régions frontalières du Mexique-États-Unis doit faire une distinction entre les «binationaux cultures politiques» et aux «cultures institutionnelles spécifiques».

Mots clés: la frontière américano-mexicaine, la culture de l'eau transfrontalière, la culture politique, bassin versant du fleuve Colorado 


\section{Resumen}

Este artículo examina la política del agua a lo largo de la frontera-oeste México-Estados Unidos (EE.UU.) en el marco de la construcción de una "cultura transfronteriza del agua". En los debates globales del agua, algunos observadores han discutido la necesidad de construir "culturas" de agua destinadas a reforzar las normas sociales que apoyen las estrategias de conservación pero también la cooperación política transnacional. Este artículo sostiene que un cambio fundamental en la cultura política a lo largo de la frontera se ha producido a través del análisis de los recientes acontecimientos ocurridos durante el periodo 2003-2010 sobre la distribución del agua en la cuenca compartida de Colorado. El artículo observa un cambio significativo de la cultura política, definida como normas basadas en la comunidad que promueven la cooperación transfronteriza en las estrategias de distribución de agua, a una conceptualización de la cultura integrada en la racionalidad, que actúa simplemente como un filtro a través del cual pasan los intereses políticos. Este importante cambio ha elevado el papel de los líderes locales en los procesos de toma de decisiones relativas a la distribución de agua. Por lo tanto, la autora sugiere que al analizar la noción de cultura en las regiones fronterizas, se debe diferenciar entre las "culturas políticas binacionales" generales, y las más específicas "culturas institucionales"

Palabras clave: la frontera México-Estados Unidos, la cultura transfronteriza del agua, la cultura política, las cuencas hidrográficas del Río Colorado 